
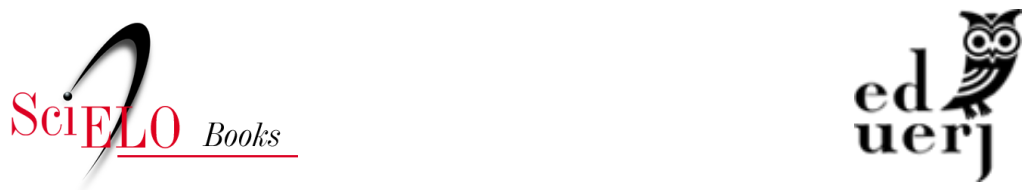

Parte II - Princípios teóricos e práticos para o cotidiano escolar de crianças, jovens e adultos em Roda de Conversas

\title{
Capítulo 6 - Fonologia aplicada à Alfabetização e ao Letramento: contribuições para a análise de manifestações ortográficas não convencionais
}

Maria Letícia Cautela de Almeida Machado

\section{SciELO Books / SciELO Livros / SciELO Libros}

MACHADO, M.L.C.A. Fonologia aplicada à Alfabetização e ao Letramento: contribuições para a análise de manifestações ortográficas não convencionais. In: FERNANDES, A.P., and LOPES, P.C., eds. $O$ cotidiano escolar de crianças, jovens e adultos em rodas de conversas [online]. Rio de Janeiro: EDUERJ, 2020, pp. 125-151. ISBN: 978-6587949-02-4. https://doi.org/10.7476/9786587949024.0008.

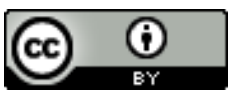

All the contents of this work, except where otherwise noted, is licensed under a Creative Commons Attribution 4.0 International license.

Todo o conteúdo deste trabalho, exceto quando houver ressalva, é publicado sob a licença Creative Commons Atribição 4.0.

Todo el contenido de esta obra, excepto donde se indique lo contrario, está bajo licencia de la licencia Creative Commons Reconocimento 4.0. 


\section{Capítulo 6 \\ Fonologia aplicada à Alfabetizaçáo e ao Letramento: contribuiçóes para a análise de manifestaçóes ortográficas não convencionais}

Maria Letícia Cautela de Almeida Machado

\section{Introdução}

No Brasil, nas últimas décadas, tem-se apontado um número crescente de alunos que não correspondem às expectativas da escola com relação à aprendizagem e ao domínio da língua escrita. Esses alunos são previamente rotulados por grupos de educadores como portadores de distúrbios na aprendizagem e, assim, encaminhados às unidades de saúde para atendimento fonoaudiológico, psicológico ou psicopedagógico. Segundo Garcia (2004), o número de encaminhamentos tem tomado tal proporção que o problema começa a ser entendido como uma questão de saúde pública.

Esses profissionais de saúde, em geral, tendem a ratificar essa visão medicalizante do problema, julgando as manifestações na escrita desses alunos como sintomáticas e atribuindo suas causas a deficiências inerentes ao sujeito. $\mathrm{O}$ aluno desviante surge, desse modo, como efeito do discurso pedagógico e médico e de seus dispositivos de normalização. 
Tais dispositivos são decorrentes de uma concepção de desenvolvimento e de aprendizagem, que vem se difundindo na formação tanto dos agentes de saúde como dos profissionais de educação, pautada, por influência da área médica, no paradigma de normalidade $\mathrm{x}$ anormalidade, a partir do qual se espera um padráo de linguagem, de comportamento e de atitudes que conduzam ao sucesso escolar.

Essa concepção normativa de desenvolvimento vem determinando a perpetuação do que Moysés (2001) define como o mito do fracasso escolar. Trata-se do mito de que questóes orgânicas sejam responsáveis, pelo menos em parte, pelo fracasso escolar. Nessa direçáo, fatos da escrita que não coincidem com escalas normativas são interpretados como déficits que podem indicar problemas inerentes ao indivíduo, autorizando que o processo de aprendizagem da escrita seja analisado por meio de critérios perpassados pelo pensamento naturalista. Tais critérios obscurecem a singularidade humana e sua profunda relaçáo com o coletivo, excluindo fatores sociais e culturais determinantes das condiçôes de domínio da língua escrita.

Segundo Massi e Berberian (2005) e Machado (2013a), essa concepção patologizante das manifestações não convencionais na escrita de alunos decorre, em parte, de uma visão reducionista acerca do processo de apropriação da língua escrita, bem como das atividades de elaboração e reelaboração de hipóteses subjacentes à aprendizagem da ortografia.

Nessa direção, Kristensen e Freire (2001) criticam atividades de alfabetização fundamentadas numa visão mecanicista, tais como cópia, ditado, leitura de frases e palavras soltas, especialmente quando essas são consideradas requisitos para a aprendizagem das regras gramaticais, de pontuação e ortografia. Com base em tal visão, hipóteses ortográficas distantes da convenção são avaliadas como erros que devem ser evitados. Dessa forma, as hipóteses, associaçóes, reflexôes que as crianças necessitam produzir para efetivamente se apropriarem da convenção ortográfica são avaliadas 
equivocadamente como sinais de distúrbios e dificuldades. Estudos de Bacha e Maia (2001), Berberian et al. (2008) e Machado (2013b) evidenciam uma tendência equivocada de educadores e profissionais da saúde, envolvidos com os chamados problemas de aprendizagem, de avaliarem negativamente erros ortográficos. Essa tendência está associada a um conhecimento restrito sobre a língua oral e a língua escrita, bem como a natureza das relaçóes que podem se estabelecer entre elas.

Diante desse contexto, este capítulo tem por objetivo apresentar e analisar alguns tipos de manifestaçôes ortográficas não convencionais recorrentes na escrita de alunos em processo de alfabetizaçáo, com vistas a fornecer elementos ao educador para a formulação de hipóteses teórico-descritivas sobre os textos de seus alunos. Pretende-se ainda apontar aspectos básicos de mediaçóes pedagógicas que favoreçam a aproximação das escritas dos alunos à escrita alfabética e ortográfica convencional.

\section{Manifestaçóes ortográficas não convencionais presentes em escritas de alunos em processos de alfabetizaçáo}

Optou-se, neste capítulo, pela abordagem de algumas ocorrências ortográficas cujas pesquisas ${ }^{1}$ apontam como de maior incidência entre alunos em processo de alfabetização: trocas, omissóes, inversóes e segmentaçôes não convencionais de palavras. Tais manifestaçôes são exemplificadas e analisadas a partir de três produçôes textuais realizadas por alunos ${ }^{2}$ do primeiro, segundo e terceiro anos do Ensino Fundamental, período oficialmente definido como

1 Como exemplos de pesquisas sobre as manifestações ortográficas dos alunos, podem ser citados: Zorzi (1998), que analisou a escrita de alunos do $2 .^{\circ}$ ao $5 .^{\circ}$ ano e Berberian et al. (2008), que compararam as manifestaçóes ortográficas presentes na escrita de alunos do $50^{\circ}$ e $9 .^{\circ}$ ano do Ensino Fundamental.

2 As produçóes escritas foram realizadas pelos alunos, em sala de aula, a partir de atividades dirigidas pela professora da turma. Os responsáveis assinaram o termo de consentimento livre e esclarecido, autorizando a divulgação para fins de pesquisa e estudo. 
128 O cotidiano escolar de crianças, jovens e adultos em roda de conversas

o ciclo de alfabetização. Esses textos são apresentados, respectivamente, nas figuras 1,2 e 3 .

Figura 1: Escrita de um aluno do $1 .^{\circ}$ ano do Ensino Fundamental

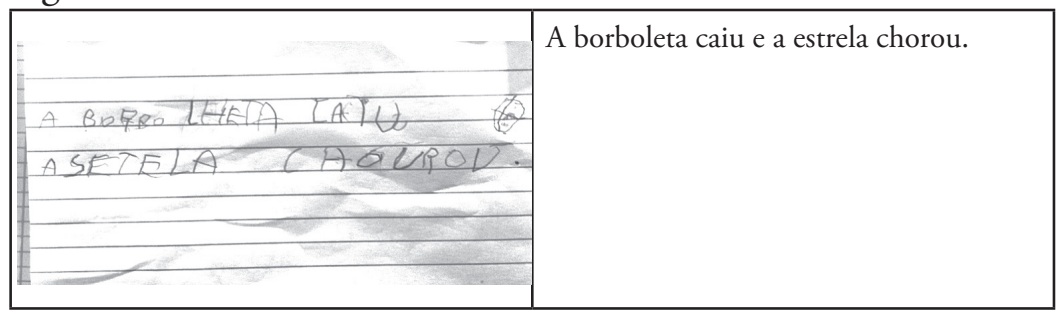

Fonte: acervo da autora.

Figura 2: Escrita de um aluno do 2. ${ }^{\circ}$ ano do Ensino Fundamental

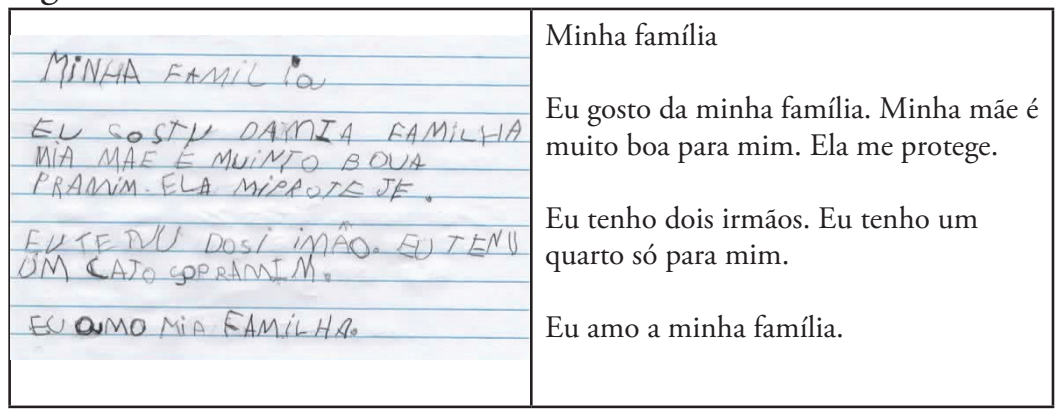

Fonte: acervo da autora. 
Figura 3: Escrita de um aluno do 3. ${ }^{\circ}$ ano do Ensino Fundamental

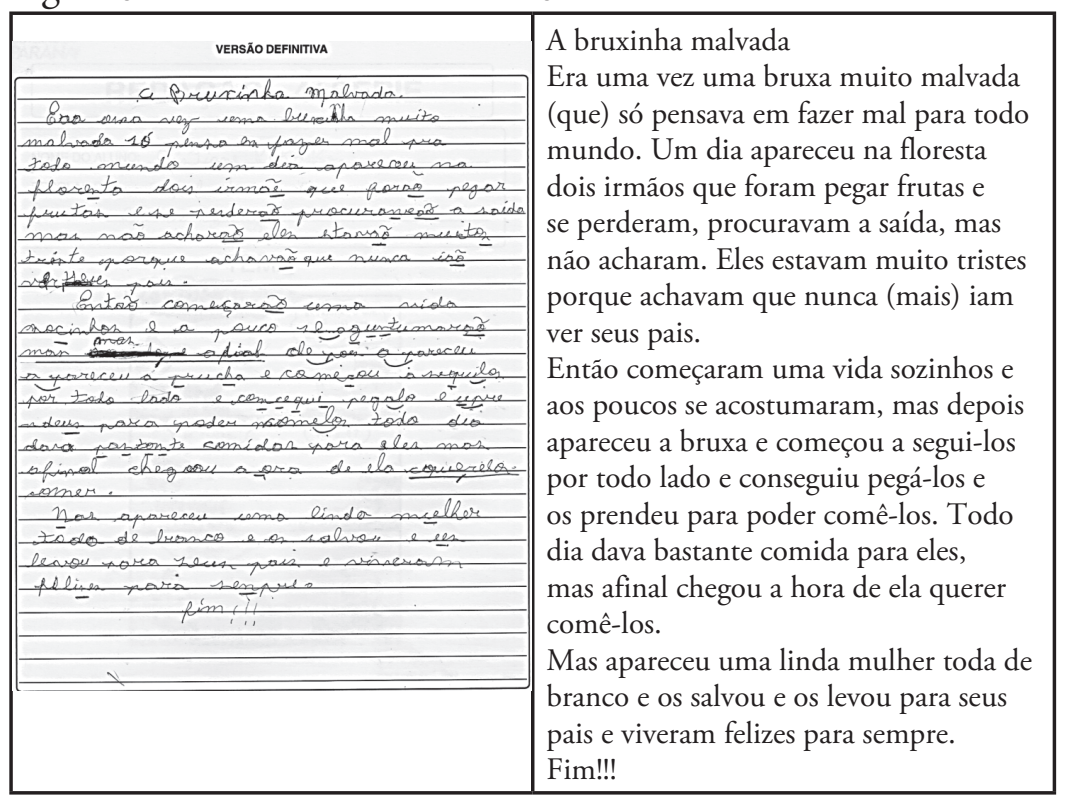

Fonte: acervo da autora.

\section{Troca de letras}

Segundo Berberian et al. (2008), a troca de uma letra por outra na grafia de uma palavra ocorre principalmente em três situaçóes: trocas que decorrem do fato de não haver formas fixas ou únicas da grafia de certos sons; trocas devido ao apoio na oralidade; e trocas caracterizadas por substituiçóes de letras correspondentes a fonemas que se diferenciam pelo traço de sonoridade. Tais manifestaçôes são abordadas ${ }^{3}$ a seguir.

3 Cabe informar que, em todo o capítulo, são utilizados traços oblíquos (/ / ) para a anotação dos segmentos fonêmicos (fonemas) ou transcriçóes fonêmicas de palavras e colchetes ([ ]) para os segmentos fonéticos ou transcriçōes fonéticas de palavras (fones, ou seja, produçôes reais, individuais dos sons). E ainda são utilizados aspas (" ”) quando se trata de anotaçóes de letras ou palavras escritas. Para representar os fonemas e fones, utiliza-se o Alfabeto Fonético Internacional (IPA). 


\section{Trocas envolvendo múltiplas representaçóes}

As trocas envolvendo as múltiplas representações são as alteraçóes ortográficas decorrentes da confusão que pode ser gerada pelo fato de não haver formas fixas ou únicas de representação gráfica de certos sons (Zorzi, 1998). Embora o sistema de escrita alfabética apresente como característica básica uma correspondência entre sons e letras (ou fonemas/grafemas), tal relação nem sempre ocorre de forma biunívoca, havendo correspondências múltiplas: um fonema pode ser escrito por várias letras, uma letra pode representar diferentes fonemas ou pode haver uma irregularidade na correspondência quantitativa entre letras e sons que compóem as palavras.

Exemplos dessas trocas podem ser observados na produção escrita apresentada na figura 2, nas palavras: "protege > proteje" e "quarto > cato"; bem como na produção escrita da figura 3, nas palavras: "foram > forão"; "perderam > perderáo"; "procuravam > procuravão"; "acharam > acharão"; "estavam > estavão"; "achavam > achavão"; "iam > ião"; "começaram > começarão"; "acostumaram > aguntumarão"; "bruxa > prucha"; "começou > comesou"; "conseguiu > comcequi"; "bastante > pastamte"; "felizes > felises" e "sempre > senpre".

Essas manifestaçôes ortográficas são muito comuns no processo de alfabetização e até mesmo nos anos escolares subsequentes. ${ }^{4}$ Essas trocas não são justificadas por uma dificuldade intrínseca ao aluno, mas pela complexidade que é inerente à própria língua escrita. Tal manifestaçáo é explicada por Faraco (2001), devido à Língua Portuguesa ter uma representação gráfica alfabética com memória etimológica. A representação gráfica alfabética implica o fato de unidades gráficas representarem unidades sonoras. Porém,

4 Embora, nesse último caso, com tendência de menor incidência, conforme apontam as pesquisas de Zorzi (1998) e Berberian et al. (2008). 
o fato de o nosso sistema gráfico ter memória etimológica desestabiliza a lógica própria da escrita alfabética. Portanto, apesar de a nossa escrita apresentar uma relaçáo unidade sonora/letra previsível, também comporta representaçôes gráficas arbitrárias e imprevisíveis.

Quando o aluno desconhece que pode haver formas diversas de escrita de um mesmo som, ele pode tomar como referência ou opção uma determinada letra, como que acreditando que, para tal som, deve-se empregar tal letra. Hipotetizando uma correspondência biunívoca, a criança pode, por exemplo, utilizar somente a letra "s" para representar o fonema /s/, como se houvesse uma representação estável entre ambos. Tal tendência pode ainda ser acentuada por métodos de alfabetizaçáo que não explicitem a complexidade de nossa língua e a existência de formas de grafar que não são fixas.

Ao compreender que um mesmo som pode ser escrito por diferentes letras e que uma mesma letra grafa diferentes sons, o aluno, mesmo sem ter o domínio ortográfico, lança dúvidas quanto às grafias possíveis, de forma mais explícita e recorrente. Essas dúvidas indicam que o aluno compreende de modo mais avançado o sistema ortográfico. Portanto, esse processo de manifestaçôes ortográficas desviantes da norma padrão evidencia estados de escrita de que o sujeito dispóe num determinado momento de seu processo de apropriação e revela que o sujeito se aproxima da escrita padrão, uma vez que não realiza escolhas aleatórias.

Nesses casos, em que o professor identifica nas escritas de seus alunos trocas por múltiplas representaçôes, a mediação pedagógica requer investimento em práticas e açóes que favoreçam aos alunos a elaboração de conceitos específicos a respeito do sistema de escrita e de suas inter-relaçôes com a fala, como, por exemplo: o que é som e o que é letra; que as letras escrevem sons; que os sons podem ser transformados em letras; que existem possibilidades variadas de relaçóes entre letras e sons; diferenciar o som que a letra representa 
do nome da letra; reconhecer o papel das regras contextuais ${ }^{5}$ na grafia das palavras; detectar as situaçóes de risco ou conflito produzidas pela própria língua e desenvolver estratégias de superação. ${ }^{6}$ No entanto, para que o professor possa mediar a construção desses conceitos pelos alunos, é fundamental que sua formação envolva um conhecimento específico sobre a língua escrita, a língua oral e sobre seus processos de aprendizagem.

Tal necessidade é ratificada, por exemplo, ao considerarmos uma manifestaçáo não convencional recorrente na produção escrita da figura 3. É possível observar que o aluno, por nove vezes em uma única produção, trocou as terminaçôes verbais "am” por "ão" ("perderam > perderáo"), em virtude da equivalência sonora que há entre elas, apostando numa representação estável desse ditongo, como se houvesse uma única opçáo de grafia. Ocorre que o professor precisa ter conhecimento dos fatos linguísticos para problematizar tal questáo com a turma. Com frequência, o que se verifica em salas de aula são professores explicando tal distinção apenas orientando seus alunos a grafarem essas terminaçóes com "am", no caso de verbos no passado, e com "áo", no caso de verbos no futuro. No entanto, tal regra não é totalmente procedente, uma vez que ambas as terminaçóes podem ser utilizadas também no presente (como em "falam" e "vão"). Além disso, há que se considerar que, para muitos alunos, especialmente aqueles em processo de alfabetização,

5 Como exemplos de regras contextuais - que interferem na grafia das palavras - a serem identificadas pelos alunos, temos a influência das vogais sobre determinadas consoantes, como o caso da letra "s" que, entre vogais, passa a ter som de /z/, como na palavra "casa", ou, ainda, no caso da letra "c", que, em contexto de palavras em que é acompanhada das vogais "a", "o" e "u", escreve o fonema / $\mathrm{k} /$, enquanto que, com "e" e "i" representa o fonema /s/. Pode ser citado também o exemplo da letra " $z$ " que em contexto de final de palavras, assume som de /s/, como na palavra "paz".

6 Como exemplos de estratégias de superação para situaçóes de risco produzidas pela própria língua, temos: buscar informaçóes sobre quais letras, entre várias, seria a correta; ou, ainda, usar o apoio gráfico - ou seja, escrever as várias opçóes de grafia daquela palavra e descartar aquelas que visualmente parecem erradas -, em vez de apenas se pautar na fala para decidir que letra usar. 
não é notória a distinção de tais tempos verbais, o que torna tal regra/orientação pouco produtiva. $\mathrm{O}$ fato linguístico relevante de distinção entre "am" e "ão" que precisa ser sinalizado em sala de aula diz respeito à tonicidade: usa-se "ão" quando a sílaba tônica do verbo é a última (pronunciando-a com mais intensidade), como em "fala[rão']", e utiliza-se "am" quando a sílaba tônica é a penúltima, como em "fa[la'] ram. ${ }^{7} \mathrm{Ou}$, dito de outro modo, o uso do til nas terminaçốes verbais ("ão") marca a sílaba tônica, embora não se trate de um acento, mas de um sinal gráfico de nasalização.

\section{Trocas devido ao apoio na oralidade}

Outro aspecto da complexa relação entre fala e escrita, que costuma causar muita confusão para os alunos em processo de alfabetização, diz respeito às variaçóes entre o modo de pronunciar as palavras e a maneira de escrevê-las. Conforme aponta Cagliari (2003a), apesar de a língua escrita portuguesa ter uma representação fonética, isso não quer dizer que ela represente a língua oral. A relação entre a língua oral e a língua escrita não se dá na forma de uma transcrição fonética, até porque a diversidade da fala não caberia na escrita padrão.

Algumas trocas ortográficas presentes em escritas de alunos em processo de alfabetização são justificadas pelo fato de apoiarem-se no modo como pronunciam as palavras para decidirem o modo de grafá-las, formulando vocábulos os quais não correspondem aos padróes da escrita. Exemplos dessas manifestaçóes podem ser observados na produção escrita apresentada na figura 2, nas palavras: "gosto > gostu"; "me > mi" e "tenho > tenu"; bem como nas palavras: "acostumaram > aguntumarão" e "os $>$ us", presentes na escrita da figura 3.

7 Há exceçôes a essa regra em alguns substantivos, como [ór']gão e [ór']fão. No entanto, observe que, nesses casos, a sílaba tônica é marcada por um acento gráfico. 
Com frequência, as trocas decorrentes de apoio na oralidade envolvem o uso das letras "u" e "l" para representar os ditongos (como em: voltou > voutou e papel > papeu); o uso das letras "e" e "i" (como em: define $>$ defini e existe $>$ existi) e o uso das letras "o" e "u" (como em: pérola > pérula; naquilo > naquilu; casulo > casulu).

Existe uma explicação linguística para os fatos que ocorrem na fala em palavras nas quais há ocorrência de /1/ pós-vocálico ("balde" [bawd.3i]) ou de vogais /e/ e /o/, em posição átona ("nave" [na'vi]; "serenos" [sere'nuS]; "ídolo" [i'dulu]).

No primeiro caso, ocorre que a consoante /l/ - anterior, lateral, linguodental -, quando assume posição pós-vocálica, torna-se posterior por alofonia posicional (Camara Jr., 2009). ${ }^{8}$ Daí, decorre uma mutaçáo, a vocalização da consoante, resultando em um /u/ assilábico, ou seja, em uma semivogal /w/, que, com a vogal anterior, forma um ditongo ("mal" $[\mathrm{maw}]) .{ }^{9}$ Isso é fato na língua oral: /1/ em posição pós-vocálica emite-se como /w/.

O problema ocorre quando o aluno, ao escrever palavras que tenham tal ocorrência, transcreve para a escrita o modo como as pronunciam - apostando em uma relação direta entre fala e escrita -, resultando em vocábulos como "soltou > soutou" ou "palpite >

8 Segundo Fromkin e Rodman (1993), os diferentes fones que representam ou derivam de um fonema denominam-se alofones desse fonema. Um alofone é, pois, uma variante fonética previsível de um fonema. Os alofones podem ser posicionais ou livres. $\mathrm{Na}$ alofonia posicional ocorre assimilação aos traços dos outros sons contíguos ou um afrouxamento ou mesmo mudança de articulaçóes em virtude da posição fraca em que o fonema se acha (Câmara Jr., 2009).

9 Assim, a palavra "mal" se torna homônima da palavra "mau", sendo pronunciadas da mesma forma: [maw]. Portanto, a distinção semântica entre "mal" e "mau" é marcada pela distinção na grafia dessas palavras, e não por qualquer distinção de pronúncia, de modo que é equivocada a conduta pedagógica de certos professores que pedem aos alunos para prestarem atenção no modo como pronunciam essas palavras para diferenciá-las, forjando, inclusive, a pronúncia do /1/ na palavra "mal”, elevando sua língua para articulá-lo como se, em posição pós-vocálica, esse fonema mantivesse seu ponto de articulação linguodental. 
paupite". A letra "l" é substituída pela letra "u", constituindo trocas por apoio na oralidade.

Nesses casos, a mediação pedagógica demanda discussôes nas quais fique claro para os alunos que não se pode pautar a escrita no modo como se fala. Faz-se necessário, ainda, trabalhar a regra ortográfica que define que, em palavras nas quais há ocorrência de ditongos desse tipo, a semivogal /w/ pode ser representada pela letra "l" (como em "sol") ou pela letra "u" (como em "sou"), tratando-se de uma convenção da língua escrita. A questão pode ser explicada como um caso de múltipla representação, ou seja, um mesmo fonema - a semivogal $/ \mathrm{w} /$ - pode ser escrito por mais de uma letra - "l" ou "u" -, dependendo da palavra. A escolha por uma ou outra grafia náo pode ser feita tendo como base a fala.

No segundo caso, em palavras nas quais há ocorrência das vogais /e/, /i/, /o/ e /u/ em posição átona, o evento fonológico que ocorre é denominado neutralização (Câmara Jr., 2009). ${ }^{10}$ Segundo Câmara Jr. (2009), nas primeiras vogais postônicas dos proparoxítonos (ou vogais penúltimas átonas), há a neutralização entre /o/ e /u/, de modo que a vogal /o/ é reduzida para/u/, como na palavra [pérola > pérula], donde a grafia com "o" ou "u" é uma mera convenção da língua escrita, pois o que se tem na fala, na realidade, é /u/. Do mesmo modo, para a vogal átona final, seguida ou não de /s/ no mesmo vocábulo, há a neutralizaçáo entre /o/ e /u/ e entre /e/ e /i/, como em [naquilo $>$ naquilu] e em [define $>$ defini]. Nesses casos, também, o que define a escrita dessas palavras com "o" ou "u" e com "e" ou "i" nada tem a ver com os sons que compóem os vocábulos, tratando-se de uma arbitrariedade ortográfica. Há, portanto, um descompasso entre o modo de pronunciar essas palavras e o modo de grafá-las (fala-se [eziSt $\int_{\mathbf{i}}$ ], mas escreve-se "existe").

\footnotetext{
${ }^{10}$ A neutralização diz respeito à redução do número de fonemas. Isto é, "mais de uma oposiçấo desaparece ou se suprime, ficando para cada uma um fonema em vez de dois" (Câmara Jr., 2009, p. 43).
} 
É primordial que tais questôes sejam abordadas e debatidas em sala de aula. Contudo, é necessário que o professor disponha desse conhecimento linguístico. Caso contrário, não compreenderá que manifestaçóes ortográficas como as apontadas nesta seção nada têm a ver com problemas intrínsecos ao sujeito, mas se justificam pela própria complexidade da língua escrita e de suas relaçóes com a fala.

Pode-se levantar, ainda, outra hipótese explicativa para essas trocas. Algumas metodologias de alfabetização recortam a língua para apresentá-la de uma maneira artificial, pondo o aluno inicialmente somente em contato com formas regulares da escrita, podendo estar reforçando a crença de que a escrita é uma transcrição da oralidade. Além disso, conduzem os alunos inicialmente a prestarem atenção ao modo de pronúncia das palavras, como se a fala fosse a determinante da escrita e, mais tarde, os recriminam por cometerem tais erros.

De maneira oposta, é primordial que as estratégias didático-pedagógicas na alfabetização contribuam para que os alunos percebam que: fala e escrita são processos distintos; há variaçôes entre o modo de falar e o modo de escrever as palavras; ${ }^{11}$ e a pista acústica-articulatória não é suficiente para definir a escrita das palavras. Faz-se necessário, ainda, levar o aluno a identificar palavras de risco, ou seja, a detectar situaçóes passíveis de "erro" e a buscar estratégias de resoluçáo de conflito (como é o caso, por exemplo, de o aluno analisar semelhanças sonoras entre palavras e perceber que determinadas categorias de palavras estáo mais sujeitas a "erros" desse tipo).

\footnotetext{
${ }^{11}$ Para que o aluno perceba a existência de variaçóes entre a fala e a escrita, o professor pode, por exemplo, pedir aos alunos para escreverem as palavras exatamente do modo como falam - na forma de uma transcrição fonética - e comparar com a forma de escrevê-las, ou ainda ouvir gravaçóes de pessoas ou músicas e identificar a maneira como as palavras são faladas nessas situações.
} 


\section{Trocas envolvendo letras correspondentes aos fonemas surdos e sonoros}

Essas alterações estão caracterizadas por substituiçóes de grupos de letras que representam pares de fonemas muito semelhantes - com o mesmo modo e ponto de articulaçáo -, opondo-se apenas pelo traço de sonoridade. ${ }^{12}$ Exemplos dessas trocas podem ser verificados na produção escrita apresentada na figura 3, nas palavras: "sozinhos > socinhos"; "acostumaram > aguntumaráo"; "bruxa > prucha"; "segui-los > sequilos"; "conseguiu > comcequi"; "bastante > pastamte".

Tais manifestaçóes se relacionam com o modo como os sujeitos representam os fonemas em suas mentes. Essa representação é determinada pela experiência cultural vivenciada pelo sujeito durante o processo de aquisição da fala. Conforme aponta Senna (2011), se a experiência cultural levar o sujeito a privilegiar a identificação de unidades dentro de um todo, esmiuçando as partes do todo e discriminando as fronteiras de cada elemento percebido, então, essa experiência cultural - marcadamente associada a um modo de pensamento científico cartesiano - gerará falantes cujos conceitos fonêmicos guardam grande distintividade entre si. Se, por outro lado, a experiência cultural levar o sujeito a privilegiar a velocidade no processo de percepção, visando a ampliar o número de experiências de mundo vividas simultaneamente - o que lhe exige um esquema de atenção multidirecional -, esse sujeito tenderá a perceber os objetos como um todo, em detrimento dos detalhes daquilo de que sáo compostos. Tais sujeitos, com modos de pensamento predominantemente narrativos, representarão os fonemas com baixo nível de discriminaçáo e sempre em relaçáo a outros fonemas com os quais ocorrem na cadeia fonética.

${ }^{12} \mathrm{O}$ traço de sonoridade determina as oposições entre fonemas vozeados - produzidos com vibraçáo das cordas vocais - e os fonemas náo vozeados - produzidos sem vibraçáo das cordas vocais. 
Essa representação de fonema, marcadamente associada a certo modelo cultural, é denominada, por Senna (2011), de macrofonema - uma entidade conceitual líquida e de baixo nível de distintividade no sistema fonológico da língua. Portanto, trata-se de uma representação fonêmica que, apesar de se tratar de uma unidade funcional, não apresenta um caráter fechado, dá-se em forma de um continuum. Desse modo, o macrofonema é uma entidade mental que transborda a noção clássica de unidade distintiva, já que sua concepçáo pressupóe zonas de aproximação a diversas outras entidades com as quais compartilha parte de suas propriedades distintivas. Assim, o sujeito representa, por exemplo, o fonema /b/ num entrelugar entre o $/ \mathrm{p} /$ e o $/ \mathrm{b} /$.

Nessa perspectiva, os fonemas não são entidades linguísticas que pertencem à gramática normativa, e sim entidades cognitivas, representaçôes mentais, enfim, são conceitos. Segundo Vygotsky (2007, p. 43), "um conceito não é uma formação isolada, fossilizada e imutável, mas sim uma parte ativa do processo intelectual constantemente a serviço da comunicação, do entendimento e da soluçấo de problemas".

Tal representação macrofonêmica não causa custo para a fala, mas pode causar dificuldades na escrita, no momento em que o aluno tiver que decidir com que letras escrever certas palavras compostas por esses fonemas muito semelhantes. Ao escrever, os alunos precisam fazer uma análise dos fonemas que compóem as palavras, evocando imagens acústicas ou sonoras. Imagens estas que, quando evocadas para análise de seus componentes, podem não ser claras o suficiente para permitir uma diferenciaçáo precisa entre sons que são muito semelhantes quanto à composição dos traços fonêmicos que os caracterizam.

Como consequência, sujeitos que apresentam uma representação macrofonêmica podem apresentar trocas de letras envolvendo os fonemas /p/ e /b/, /t/ e /d/, /k/ e /g/, /f/ e /v/, /s/ e /z/, /J/ e /3/. Diferentemente, alunos que representam fonemas em unidades 
altamente distintivas encontram facilmente suas unidades equivalentes na escrita.

A essa hipótese, acrescentam-se possíveis dificuldades quanto a conhecer, com exatidáo, qual letra corresponde exatamente a qual som. Aqueles alunos em que as realizaçóes fonéticas dos fones ou até mesmo as representaçóes mentais dos fonemas surdos e sonoros estão muito próximas umas das outras terão dificuldades em reconhecer qual letra se associa a qual som, podendo, inclusive, ter uma única representação mental para os dois sons.

Outra explicaçáo dada a essas trocas faz referência ao fato de que os alunos são, em geral, ensinados a escrever em silêncio, o que dificulta ou impede que se deem conta dos sons que compóem tais palavras, não tendo pistas acústicas ou sonoras para detectar que tipo de fonema - surdo ou sonoro - está presente. Ocorre que, quando articulados sem som ou sussurrados, os fonemas sonoros tendem ao ensurdecimento, o que pode ser a razão pela qual as consoantes sonoras tendem a ser substituídas pelas consoantes surdas com muito mais frequência do que o inverso (Cagliari, 2003b).

No caso de identificação desse tipo de troca na escrita de alunos em processo de alfabetização, a mediação pedagógica pressupóe um trabalho que envolva a consciência fonológica, de modo que o aluno possa refletir sobre as relaçóes fonema $\mathrm{x}$ grafema. Pode-se planejar atividades, discussóes e análises que permitam aos alunos o entendimento de que existem pares de fonemas muito semelhantes, que se diferenciam pelo traço de sonoridade. Além disso, nesses casos, é oportuna a sinalização de qual letra escreve cada um desses pares de fonemas.

Vale lembrar que, em turmas de alfabetização, é primordial que o professor esteja atento aos processos de desenvolvimento da fala de seus alunos. Como essas trocas entre fonemas surdos e sonoros estão relacionadas aos processos de percepção, produção e representação da língua oral, na persistência desse tipo de troca na escrita, é fundamental um encaminhamento para avaliação fonoaudiológica. 


\section{Omissão de letras}

As omissóes se referem às palavras grafadas de modo incompleto, em virtude da supressão de uma ou mais letras. Assim como nas trocas, as omissóes de letras nas palavras não se manifestam de forma aleatória. Ocorrem, principalmente, no uso de determinadas letras em construçôes ou contextos silábicos específicos, evidenciando reflexóes do aluno sobre a escrita que está sendo construída.

Exemplos de omissóes podem ser verificados na produção escrita apresentada na figura 1, na palavra "estrela > setela"; na figura 2, nas palavras: "minha > mia"; "tenho > tenu"; "irmáos > imáo" e "quarto > cato"; ou na figura 3, nas palavras: "bruxinha > buxinha"; "conseguiu >comcequi"; "hora > ora".

Os estudos de Abaurre et al. (1997) contribuem para a formulação de hipóteses teórico-descritivas sobre essas manifestações na escrita. Segundo os autores, os alunos tendem a produzir escritas iniciais de acordo com a forma canônica da língua (consoante-vogal: cv). Portanto, o fato de o aluno suprimir letras em sílabas complexas (cvc - consoante-vogal-consoante, vc-vogal-consoante e ccv - consoante-consoante-vogal) pode ser explicado como uma tentativa de seguir a ordem canônica da língua.

Reforçando tal tendência, há ainda metodologias de alfabetização que enfatizam, por tempo prolongado, o processo de aprendizagem a partir de palavras construídas com sílabas formadas regularmente por consoantes e vogais (cv). Tal conduta leva o aluno a associar à escrita uma regularidade que náo existe.

Por motivo semelhante, os alunos tendem a suprir a letra " $h$ " em dígrafos, como nas palavras "tenho > tenu" e "hora > ora". Confiantes em uma regularidade na relação entre a escrita e a fala, apostam equivocadamente numa equivalência quantitativa entre o número de sons e de letras que compóe as palavras. Metodologias tradicionais de alfabetização em que os dígrafos são apresentados à criança apenas no final da cartilha - como se o aluno não 
vivenciasse a escrita em toda a sua complexidade diariamente ao se deparar com os portadores reais de textos - apenas corroboram para que o aluno cometa esse tipo de "erro".

Outra hipótese que os alunos realizam e pode resultar em omissóes envolvendo as letras "r", "l", "s" e "m" - em palavras como "fazer $>$ faze", "flauta > fauta", "respiramos $>$ respiramo" e "gostaram > gostaro" - diz respeito ao apoio na oralidade e às variaçóes linguísticas. Com base em modos de fala, os alunos escrevem formulando vocabulários, concordâncias verbais e nominais, os quais não correspondem à norma padrão da escrita.

Entre os exemplos elencados acima, nos deteremos, em especial, naqueles que envolvem a supressão das letras " $r$ " e " $s$ ", pelo fato de ser uma manifestação recorrente na escrita não apenas de alunos em início de alfabetização como também entre sujeitos já alfabetizados, como se evidencia tanto em salas de aula quanto em pesquisas como a de Senna (1991), Zorzi (1998) e Berberian et al. (2008).

Com relação à omissão do " $\mathrm{r}$ " em final de palavras, esse tipo de manifestação é decorrente de fatores fonológicos, em desenvolvimento na língua oral, que interferem no emprego da língua escrita. De acordo com Senna (1991), a regra fonológica que gera esse tipo de interferência no uso da língua escrita é a seguinte: $\mathrm{o}$ arquifonema vibrante /R/ passa a zero quando segue vogal tônica em fronteira de palavra. Essa regra é amplamente empregada na fala, abrangendo todas as formas verbais fonologicamente compatíveis.

O que ocorre é que o sujeito não utiliza esse som na fala e muitas vezes não tem nem consciência da existência dele, uma vez que pode ter adquirido essas palavras na língua oral com o arquifonema /R/ já apagado, e, assim, sua ortografia passa a ter caráter idiossincrático. $\mathrm{O}$ fato é que os alunos erram a forma ortográfica das palavras porque se baseiam nas regras fonológicas da língua oral, apostando numa relaçáo direta entre som e letra (ou fonema/grafema). 
Nessa direção, é preciso considerar que a fala é uma prática linguística suscetível a variaçóes, e a escrita padrão segue, conforme Massini-Cagliari (2001), uma convenção que constitui uma única maneira de representarmos graficamente as palavras.

Quanto à supressão da letra "s" em fronteira de palavras, ela ocorre em nível morfossintático, envolvendo o emprego da concordância de número. O sistema de concordância gramatical do português escrito e de alguns registros do português oral tem por característica a redundância na referência ao plural. No entanto, na língua oral, há, em geral, tendência a se suprimir a informação redundante relativa ao número.

De acordo com Senna (1991, p. 63), esse apagamento ocorre em decorrência de inúmeras variáveis:

a frequência de uso de determinado termo na língua oral (quanto maior, maior a possibilidade de apagamento de marcas de plural, e vice-versa); o número total de elementos constituintes do sintagma nominal; a clareza ou ênfase em determinada palavra (o acento fonológico aumenta a incidência de marcas de plural); a distância entre o primeiro termo marcado com plural e o verbo (quanto maior, maior a incidência de marcas no verbo, e vice-versa); e muitos outros (Senna, 1991, p. 63).

O que ocorre é que muitos alunos transportam esse fato para a escrita, levando à ocorrência de omissão de marcas de plural e gerando o que se denomina como "erro" de concordância; como, por exemplo, um aluno que fale [aS menina supeR poderoza $\varepsilon$ tudo supeR eSpeRta] poderia escrever essa frase como "as menina superpoderosa é tudo super esperta”, quando, pela norma da escrita, deveria ser grafado como "as meninas superpoderosas são superespertas".

Novamente, nesse caso, o que rege esse tipo de ocorrência é o fato de o sujeito apostar numa relação direta entre fala e escrita. $\mathrm{O}$ apagamento de marcas de plural na fala diz respeito a uma variação 
linguística por que vem passando a língua oral, e, dependendo do contexto, não representa um problema. Além disso, não ocorre apenas entre grupos sociais minoritários, tal como se poderia esperar. Já na escrita padrão, essa manifestação não é aceita, pois ela não se condiciona aos usos dos seus usuários, sendo uma convenção arbitrariamente definida.

O processo de variação linguística por que passa a língua oral é, na maioria das vezes, inconsciente e, sempre, independente de regras ou padróes socialmente impostos, diferentemente do que ocorre na língua escrita. Os fatores que geram mudanças na fala e na escrita são distintos: em língua oral, são os universais da variação linguística e em língua escrita são acordos formais entre autoridades políticas, comprometidos ou não com as regras da língua oral (Tarallo, 1986).

Diferentemente dos casos de omissão do " $\mathrm{s}$ " em fronteira de palavras, a supressão do " $\mathrm{s}$ " em outras posiçóes no vocábulo - como em "gosta > gota" - pressupóe motivação distinta. Provavelmente se justifica por falhas na análise fonêmica da palavra ou por desconhecimento de como tal combinaçáo de sons deve ser grafada.

Em todo caso, a identificaçáo de omissóes na escrita de alunos demanda uma mediação pedagógica que contemple a segmentação de palavras, de modo a detectar todos os sons que as compóem; a correspondência entre som e letra; a distinção entre o som que a letra representa e o nome da letra; bem como a compreensão das várias possibilidades de construção de sílabas (v, cv, vc, cvc, ccv, crv, ccrc, ccvcc etc.).

\section{Inversóes}

As inversōes referem-se às palavras que apresentam letras em posição invertida no interior da sílaba, ou mesmo sílabas em posição distinta daquela que deveriam ocupar dentro da palavra. 
De acordo com Cagliari (2003a), algumas manifestações ortográficas acontecem pelo fato de o aluno ainda não dominar a sequência das letras nas sílabas. Nesses casos, o sujeito já internalizou a possibilidade de ocorrência de sílabas complexas, diferentemente, por exemplo, de alunos que omitem letras porque apostam na regularidade da sílaba canônica (cv). No entanto, embora reconheça que a sílaba possa ser composta por um número variável de letras, o aluno ainda não é capaz de determinar exatamente a posição de cada um dos componentes da sílaba.

As inversôes, com frequência, envolvem as letras "r" e "l" em

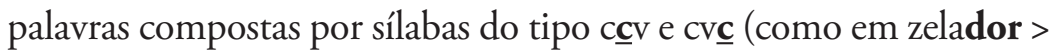
zeladro; preguiça > perguiça e flor $>$ fol), uma vez que apresentam uma forma de composição mais difícil de grafar, além de o " $\mathrm{r}$ " e o "l" serem letras de muita mobilidade, já que podem aparecer em lugares distintos na palavra.

Os alunos que cometem esses "erros" estão mostrando que são capazes de identificar a presença dos sons que compóem as palavras, mas não têm segurança acerca de qual a posição exata que as letras que representam tais sons devem ocupar dentro da sequência.

Outras inversões comuns são aquelas nas quais sílabas de estrutura vc tornam-se $\underline{\mathbf{c}}$, como podem ser verificadas na produção escrita da figura 1, na palavra "estrela > setela" e na palavra "dois > dosi", da figura 2, bem como em palavras como "arco > raco". Esses casos indicam, mais uma vez, que os alunos, no início do processo de aprendizagem da escrita, tendem a seguir a forma canônica da língua (cv), tratando-se, portanto, de um ajuizamento do aluno a respeito do sistema de escrita, e não simplesmente um "erro".

Cabe ao professor, nesses casos, planejar estratégias e propostas didático-pedagógicas que possibilitem ao aluno reflexóes sobre a língua escrita, abordando, em especial, as correspondências entre sons e letras; as distinçóes entre oralidade e escrita; o conhecimento da estrutura silábica do português; bem como as demais convençôes da escrita. 


\section{Segmentaçóes não convencionais de palavras}

A segmentação das palavras no enunciado se define pela ocorrência de pausas ou separaçóes. A segmentaçáo das palavras está associada à representação morfológica do léxico e, tal como no caso das tensôes entre representaçóes fonológicas macrofonêmicas e grafemas, segundo Senna (2011), a representação morfológica do léxico pode, igualmente, variar muito entre a escrita e a fala, sem prejuízo para a comunicaçáo oral, porém provocando custo no processo de alfabetização.

Machado (2013a) sinaliza que a palavra pode náo ter sido representada pelo sujeito em seu léxico da forma legitimada na cultura escrita, em unidades discretas, equivalentes às classes de palavras definidas pela gramática normativa tradicional, mas em uma cadeia de elementos, em unidades contínuas que indicam, ao mesmo tempo, uma informação semântica e gramatical. Isso ocorre porque a palavra representada na mente humana não é necessariamente uma unidade que corresponda àquilo que é dicionarizado.

Assim, tomemos como exemplo a palavra "burro" - a vogal temática "o" integra uma informação gramatical ao radical "burr" e é expressa aglutinada a ele (ou seja, faz parte da palavra). Da mesma forma, nas palavras "burr[aria]", "burr[ice]", "burr[ada]", a informação gramatical está aglutinada ao radical. No entanto, na expressão "o burro", o termo determinante "o" - que também integra uma informação gramatical ao radical - é expresso separadamente, constituindo, na verdade, outra palavra nos termos da gramática normativa.

Desse modo, é perfeitamente imaginável que alunos que estejam em processo de alfabetização, em uma situação de escrita de um texto, ao terem que definir as fronteiras das palavras que deverão empregar, levantem a hipótese de que, para grafar a informação semântica e gramatical contida na expressão "o burro", seja preciso aglutinar tais informaçôes numa única "palavra": "oburro". 
Esse tipo de manifestação na escrita não pode ser tomado simplesmente como um "erro" ortográfico. Essa escrita foi direcionada pela maneira como o sujeito representa as palavras em seu léxico, que é diferente daquela prevista pela gramática normativa.

Assim, alunos em processo de alfabetização seguem formulando escritas como as exemplificadas nas figuras 2 e 3: "da minha > damia"; "para mim > pramim"; "me protege > miproteje"; "só para mim > sopramim"; "se acostumaram > seaguntumarão", "segui-los > sequilos"; "pegá-lo > pegalo". Essa macrorrepresentação de palavra é exequível na fala, mas não cabe na escrita padrão, uma vez que não coincide com as palavras tal como definidas pela gramática normativa.

Uma explicação complementar para o problema das fronteiras das palavras, ou seja, para o fato de grupos de alunos segmentarem as palavras no texto escrito de forma não convencional, pode ser dada a partir do conceito linguístico grupo de força. De acordo com Câmara Jr. (2009), um grupo de força é uma cadeia fonética que o falante emite em um único continuum, sem nenhuma pausa. Grupos de força formam os vocábulos fonéticos. As fronteiras entre os vocábulos fonéticos e as palavras convencionais raramente coincidem e podem variar conforme as situaçóes de uso, pois os falantes alteram os contornos entonacionais da fala para imprimirem realce a este ou aquele termo. Um exemplo de distribuição de grupos de força em uma representação fonética para a frase "esse moleque não vai passar de ano" poderia ser: [simuleki' nũvai' pasa' dianu]. Sujeitos que não tenham o domínio das fronteiras de palavras empregadas na escrita e que façam uso de uma fala em que vigorem grupos de força podem derivar em seu léxico palavras que correspondem ou a grupos de força ou a partes dos grupos de força, como, por exemplo: "simulequi nuvai passa dianu".

Berberian (2003) ratifica tal entendimento ao afirmar que grupos tonais, acentuação tônica, conjunto de sons ditos em determinada altura e intensidade ou unidades de fala, que recebem um 
contorno entonacional particular, podem ser utilizados pelos alunos como critérios para segmentação de sua escrita. Holden e Macginitie (apud Chacon, 1998) também contribuem ao afirmarem que a concepção que os sujeitos têm de limites de palavras frequentemente refletem o ritmo da fala ao invés de definiçóes tradicionais de palavras.

Desse modo, manifestaçóes escritas de alunos como nos enunciados "em cima > encima"; "por isso > porisso"; "a gente > agente", denominadas por Abaurre e Silva (1993) de "hipossegmentações" (junção não convencional das palavras), não indicam um "erro" ortográfico arbitrário, nem tampouco um sintoma de um problema orgânico individual. Essas manifestaçôes não convencionais se justificam no fato de sujeitos transportarem para a escrita o conceito de palavra tal qual representam sua fala em seu léxico - em unidades contínuas e não discretas.

Esses casos de "hipossegmentaçôes" na escrita envolvem frequentemente artigos, pronomes, preposiçóes e formas auxiliares de verbos. Isso se justifica no fato de esses elementos não adquirirem um estatuto autônomo com direito a recorte para sujeitos que apresentam uma representação das palavras que difere daquela ditada pela gramática normativa.

Um processo inverso, chamado por Abaurre e Silva (1993) de "hipersegmentaçôes" (separação não convencional das palavras), também pode ser verificado em escritas de alunos em processo de alfabetização, tais como no texto da figura 3, nas palavras: "depois $>$ de pois" e "apareceu > a pareceu". Essas manifestaçôes podem denotar que o sujeito está se utilizando de conhecimentos que já possuem sobre a escrita. Além disso, o fato de ele segmentar, não escrevendo a partir do conceito de palavras como unidades contínuas, mas como unidades discretas, mostra que consegue fazer uma diferenciação entre a fala e a escrita.

Esse tipo de fenômeno foi pesquisado por Cagliari (2003a), que afirma que o aluno, ao recorrer à hipersegmentação, mostra 
que já tem conhecimento sobre as convençóes da escrita, percebendo que existem maneiras de iniciar frases e textos por unidades como "da”, "do", "e”, “em”, “a”. Dessa forma, o sujeito lança mão desse conhecimento ao escrever palavras como "demais > de mais", "comigo > com migo" ou "embora > em bora".

Assim, tanto no caso das hipossegmentaçóes como nas hipersegmentaçóes, estáo envolvidas palavras como artigos, pronomes e preposiçóes. Sendo que, nos casos de hipersegmentaçóes, a justificativa é inversa ao que ocorre nas hipossegmentaçóes, ou seja, os alunos, ao assumirem que esses elementos são autônomos e têm direito a recortes, os separam ao grafarem palavras como "conversou > com versou". Tal fato pode ser indicativo de que o sujeito apresenta uma forma de representação morfológica do léxico tal como aquela da cultura escrita, além de um domínio crescente não apenas dos aspectos ortográficos da língua escrita como também dos aspectos morfológicos.

Enfim, quando o aluno toma decisões sobre a segmentação de seu texto, mostra sua percepção, ora de aspectos constitutivos da língua oral, ora de aspectos que caracterizam o texto escrito. Para além do que simplesmente "erros", tais manifestaçôes precisam ser encaradas pelos professores como modos de seus alunos conceberem a escrita.

É primordial que os professores estejam atentos à ocorrência dessas manifestaçôes nos textos de seus alunos para que possam mediar a aproximação dessas escritas à escrita padrão. Tal mediação inclui estratégias didático-pedagógicas que envolvam um trabalho de consciência fonológica no nível da palavra, de modo que o aluno reflita sobre: o que são enunciados/textos; o que são palavras; como se constituem os enunciados e as palavras; o fato de que existem palavras de diferentes extensóes e composições silábicas, bem como também é variável o tamanho dos enunciados; a variação entre o ritmo da fala e o modo de segmentar a escrita; além do papel da pontuação como marcador de aspectos interfrasais. 


\section{Consideraçóes Finais}

A partir do exposto, evidencia-se que boa parte das dificuldades apresentadas pelos alunos na elaboração de suas escritas diz respeito não a uma patologia inerente ao sujeito, mas a uma incompreensão da natureza da relaçáo entre a língua escrita e a língua oral. Muitos alunos apostam numa relação direta, como se fosse possível a escrita transcrever a fala. Essa crença se deve, pelo menos em parte, à maneira como a língua escrita tem sido ensinada nas escolas.

Portanto, o ponto central de toda a discussão é a necessidade de uma revisão da concepção de escrita como transcodificação ou mesmo representaçáo da fala, tanto por parte dos alunos como dos próprios professores. É primordial uma abordagem didático-pedagógica que explicite, logo no início do processo de alfabetizaçáo, a complexidade da escrita e de suas relaçóes com a língua oral. Isso inclui a problematização de: o que é a escrita e a fala; as características, as condiçôes de produção e os usos possíveis dessas duas línguas; a convencionalidade e a arbitrariedade da escrita; as relaçóes variáveis entre as unidades de materialização da fala e da escrita. Enfim, é preciso não camuflar a complexidade dessas línguas.

Além disso, é imprescindível que os educadores revejam suas concepçóes de "erro" na escrita. Apesar do discurso muito presente em grande parte das escolas de que o "erro" faz parte do processo de construçáo da escrita, tem sido recorrente o encaminhamento de alunos para fonoaudiólogos, psicólogos e psicopedagogos, porque são vistos pelos professores como portadores de um problema de aprendizagem da escrita. Contrariamente ao discurso, na prática, não se entende o "erro" como o próprio processo de o sujeito se aproximar da língua escrita e de sua apropriação. Muitas patologias estão sendo artificialmente criadas a partir de uma visão de "erro" enquanto sintoma inegável, ou evidente, de um distúrbio. 
A análise de escritas de alunos empreendida neste capítulo buscou demonstrar que as manifestaçôes ortográficas não convencionais representam muito mais do que "erros produtivos" - na concepção mais tradicional do termo -, mas estados de escrita legítimos, que evidenciam atitudes individuais de reflexóes e um raciocínio coerente dos alunos a respeito da língua escrita e do tipo de relação que esta estabelece com a fala. Trata-se da maneira como os diferentes sujeitos compreendem e constituem suas escritas. E esse processo de constituição se modifica constantemente, em razão da história de interação do aluno com a linguagem e com os outros, especialmente os adultos que mediam seu percurso de aprendizagem.

\section{Referências}

ABAURRE, B. M. et al. Cenas de aquisição da escrita: o sujeito e o trabalho com o texto. Campinas: Mercado de Letras, 1997.

e SILVA, A. "O desenvolvimento de critérios de segmentação na escrita". Temas de Psicologia, v.1, n.1, pp. 89-102, São Paulo, 1993.

BACHA, S. M. C. e MAIA, M. B. A. "Ocorrência de erros ortográficos: análise e compreensão". Pró-Fono - Revista de Atualização Científica, v. 13, n. 2, pp. 219-226, Carapicuíba, set. 2001.

BERBERIAN, A. P. "Princípios Norteadores da Avaliação Clínica Fonoaudiológica de Crianças Consideradas Portadoras de Distúrbios de Leitura e escrita”. In et al. (org.). Linguagem escrita: referenciais para a clínica fonoaudiológica. São Paulo: Plexus, 2003, pp. 11-38.

et al. "Análise de ocorrências ortográficas não convencionais produzidas por alunos do Ensino Fundamental". Tuiuti: ciência e cultura, Curitiba, n. 39, pp. 23-39, Curitiba, 2008.

CAGLIARI, L. C. Alfabetização e Linguística. 10. ${ }^{a}$ ed. São Paulo: Editora Scipione, 2003 . 2003b.

. Alfabetizando sem bá - bé - bi - bó - bu. 4.a ed. São Paulo: Scipione,

CAMARA JR., J. M. Estrutura da língua portuguesa. 42.a ed. Petrópolis: Vozes, 2009. 
CHACON, L. Ritmo da escrita: uma organização do heterogêneo da linguagem. São Paulo: Martins Fontes, 1998.

FARACO, C. A. Repensando a Lingua Portuguesa: escrita e alfabetização. São Paulo: Contexto, 2001.

FROMKIN, V. e RODMAN, R. "Fonologia: os modelos sonoros da língua". In e . Introdução à Linguagem. Trad. Isabel Casanova. Coimbra: Editora Almedina, 1993, pp. 75-117.

GARCIA, A. L. M. "Fonoaudiologia e Letramento". In DAUDEN, A. T. B. C. e MORI-DE ANGELIS, C. C. Linguagem escrita: tendências e reflexóes sobre o trabalho fonoaudiológico. São Paulo: Editora Pancast, 2004, pp. 15-35.

KRISTENSEN, C. R. e FREIRE, R. M. "Interpretação da escrita infantil: a questão da autoria”. Distúrbios da Comunicação, São Paulo, v. 13, n. 1, pp. 19-47, dez. 2001.

MACHADO, M. L. C. A. A escrita alfabética, sua natureza e representação: contribuiçôes à Fonoaudiologia aplicada à Educação (tese). UERJ, 2013a.

. "Propriedades gramaticais e representacionais da fala e da escrita: subsídios para a formulação de hipótese teórico-descritiva para a produção escrita dos alunos". Revista Educação e Cultura Contemporânea, v. 10, pp. 95-118, 2013b.

MASSI, G. A. e BERBERIAN, A. P. "A clínica fonoaudiológica voltada aos chamados distúrbios de leitura e escrita: uma abordagem constitutiva de linguagem". Revista da Sociedade Brasileira de Fonoaudiologia, v. 10, n. 1, pp. 43-52, jan-mar 2005.

MASSINI-CAGLIARI, G. O texto na alfabetização: coesão e coerência. Campinas: Mercado das Letras, 2001.

MOYSÉS, M. A. A. A institucionalização invisivel: crianças que não-aprendem-na-escola. Campinas: SP: Mercado de Letras, 2001.

SENNA, L. A. G. Pequeno manual de linguística geral e aplicada. Rio de Janeiro: LAG Senna, 1991. Disponível em: www.senna.pro.br. Acesso em: 1 set. 2009.

. "Psicolinguística e sistemas gramaticais no campo da psicopedagogia". In GODOY, E. e SENNA, L. A. Psicolinguistica e Letramento. Curitiba: Editora IBPEX, 2011, pp. 129-194.

TARALLO, F. A pesquisa sociolinguística. São Paulo: Ática, 1986.

VYGOTSKY, L. S. A formação social da mente: o desenvolvimento dos processos psicológicos superiores. 7. ${ }^{\text {a }}$ ed. São Paulo: Martins Fontes, 2007.

ZORZI, J. L. Aprender a escrever: a apropriação do sistema ortográfico. Porto Alegre: Artes Médicas, 1998. 